\title{
TINJAUAN MAKROSKOPIK KEPADATAN LALU LINTAS BERDASARKAN KONSEP
} DINAMIKA FLUIDA

\author{
Oleh \\ Viska Noviantri \\ Bina Nusantara University \\ Email: viskanoviantri84@gmail.com
}

\begin{abstract}
Abstrak
Analisis kepadatan lalu lintas dilakukan sebagai dasar untuk menyusun rekayasa lalu lintas dalam mengurangi kemacetan. Kepadatan lalu lintas pada ruas jalan dan waktu tertentu dapat direpresentasikan melalui pendekatan makroskopik. Pendekatan ini meninjau arus lalu lintas sebagai suatu aliran fluida dengan kendaraan sebagai partikelnya. Melalui pendekatan ini, kita dapat melihat hubungan antara kepadatan, kecepatan, dan fluks lalu lintas. Pertama-tama, diasumsikan bahwa kecepatan dan kepadatan lalu lintas memiliki hubungan yang non linear, yang lebih dikenal dengan model LWR (Lighthill Witham Richards). Model ini diselesaikan secara analitik dengan menggunakan metode karakteristik. Sedangkan secara numerik, model diselesaikan dengan menggunakan metode beda hingga. Hasil simulasi menunjukkan bahwa adanya kesesuaian antara hasil analitik dan numerik. Pada bagian akhir, akan dianalisa hasil dari simulasi untuk melihat dan menganalisa faktor-faktor yang dapat mempengaruhi kepadatan, kecepatan, dan fluks lalu lintas.
\end{abstract}

Kata Kunci : Transportasi, Kepadatan Lalu Lintas, Dinamika Fluida, Makroskopik \& LWR

\section{PENDAHULUAN}

Transportasi merupakan sarana penting sebagai salah satu faktor pendukung berkembangnya suatu kota. Namun perlu disadari bahwa perkembangan transportasi ini juga menimbulkan permasalahan baru seperti kemacetan di kota-kota besar. Kemacetan adalah suatu keadaan padatnya atau terhentinya lalu lintas yang disebabkan adanya ketidak sesuaian antara jumlah kendaraan dengan kapasitas jalan.

TomTom, salah satu perusahaan teknologi yang mengatur lalu lintas, merilis Indeks Lalu Lintas pada tahun 2018. Perusahaan ini menyoroti tingkat kemacetan pada 403 kota di 56 negara. Menurut laporannya, Jakarta termasuk ke dalam nominasi kota dengan tingkat kemacetan tertinggi. Jakarta berada di urutan ke-7, setelah Istanbul, dengan tingkat waktu ekstra perjalanan yang dibutuhkan sebesar 53\%. Bukan hanya Jakarta yang mengalami masalah kemacetan. Banyak kota-kota besar mengalami masalah yang sama. Bahkan, kemacetan bukan hanya terjadi di jalan biasa saja. Jalan tol yang merupakan jalan bebas hambatan pun tidak terlepas dari masalah kemacetan ini.

http://ejurnal.binawakya.or.id/index.php/MBI
Banyak upaya yang telah dilakukan untuk mengurangi tingkat kemacetan di Jakarta. Pada tahun 2016, pemerintah mengeluarkan aturan 3 in 1 untuk beberapa ruas jalan protokol untuk rentang waktu tertentu di Jakarta. Aturan ini mewajibkan setiap kendaraan beroda empat harus berisi minimal tiga orang. Aturan ini ternyata tidak efektif karena masih banyak orang yang tidak bertanggung jawab mencari celah.

Penelitian mengenai karakteristik lalu lintas secara mikroskopik pernah dilakukan (Mardiati. R, 2014). Pada penelitian ini, karakteristik lalu lintas dilihat berdasarkan masing - masing kendaraan. Perilaku atau cara mengemudikan kendaraan menjadi faktor yang sangat penting. Hal ini terjadi karena perilaku satu kendaraan, akan berpengaruh pada pola perilaku kendaraan lainnya. Model perilaku kendaraan di modelkan menggunakan logika fuzzy.

Metode untuk mengurangi kemacetan lalu lintas melalui penyeimbangan beban ke berbagai ruas jalan pernah dibahas oleh (Harahap. E, 2017). Melalui metode ini diharapkan beban lalu lintas terbagi secara merata

Vol.14 No.4 Nopember 2019 
ke berbagai jalur alternatif sedemikian sehingga antrian panjang kendaraan dapat dihindari. Pada penelitian ini, metode tersebut dievaluasi efektifitasnya melalui pendekatan teori antrian. Teori ini di simulasikan menggunakan algoritma Round Robin dan Random. Hasil simulasi menunjukkan bahwa metode ini dapat dijadikan sebagai salah satu solusi alternatif untuk mengurangi kemacetan.

Penelitian mengenai analisa keputusan untuk mengambil jalur lau lintas yang disukai juga pernah dibahas. (Tomara. A. S., 2018) memberikan gambaran mengenai probabilitas setiap jalur yang mungkin dengan mempertimbangkan informasi lalu lintas real time seperti jarak dan kondisi jalan. Gambaran informasi ini kemudian dikombinasikan melalui regresi logistik dengan logika fuzzy untuk memungkinkan pengambilan keputusan dalam skenario yang tidak pasti. Metode ini memerlukan parameter seperti jarak, kondisi cuaca, lokasi jalan, hari dalam seminggu dan waktu.

Dengan latar belakang yang telah diuraikan diatas, maka penulis tertarik untuk membahas permasalahan lalu-lintas secara makroskopis melalui pendekatan dinamika fluida. Penerapan dinamika fluida pada arus kepadatan jalan bisa dianalogikan sebagai sebuah partikel pada sebuah aliran fluida, dimana masing-masing partikel dianggap serupa dan ditinjau secara global.

Penerapan dinamika fluida tersebut akan dimodelkan secara matematis dan dicari solusi analitiknya. Dengan model matematika tersebut akan diperoleh informasi tentang arus kepadatan jalan, seperti kecepatan rata-rata partikel, volume kendaraan dalam satuan waktu, dan juga kepadatan kendaraan di sebuah ruas jalan. Hasil tersebut bisa digunakan untuk mempelajari keterkaitan sifat permasalahan yang sedang diselidiki dengan data-data yang diperoleh, juga untuk menganalisis dan memprediksi keadaan lalu-lintas.

Analisis dan prediksi dari pemodelan tersebut dapat digunakan sebagai dasar prtimbangan ketika akan menentukan suatu rekayasa lalu lintas. Dengan demikian, penelitian ini diharapkan dapat membatu menganalisa jenis rekayasa seperti apa yang dapat memberikan hasil yang optimum dalam mengurangi kemacetan.

\section{LANDASAN TEORI Model LWR}

Kepadatan lalu lintas dimodelkan secara makroskopik melalui model LWR (Lighthill, William, 1955). Pada model ini, kondisi lalu lintas dianalogikan sebagai aliran fluida dengan mengasumsikan kendaraan sebagai partikel yang berada pada aliran tersebut. Melalui hukum konservasi massa, diperoleh bahwa model LWR dirumuskan secara matematis oleh persamaan diferensial parsial hiperbolik sebagai berikut:

$$
\frac{\partial \rho(x, t)}{\partial t}+\frac{\partial q(\rho)}{\partial x}=0
$$

dimana $\rho(\mathrm{x}, \mathrm{t})$ merepresentasikan kepadatan (jumlah kendaraan per satuan jarak) lalu lintas pada suatu titik $x$ dan waktu t, sedangkan $\mathrm{q}(\rho)$ merepresentasikan fluks (jumlah kendaraan per satuan waktu) lalu lintas pada kepadatan tertentu. Perhatikan bahwa fluks lalu lintas merupakan fungsi yang diberikan oleh

$$
q(\rho)=\rho V(\rho)
$$

dengan $\mathrm{V}(\rho)$ adalah kecepatan lalu lintas pada kepadatan tertentu.

Hubungan antara kecepatan dan kepadatan lalu lintas diberikan secara non linear, yaitu

$$
V(\rho)=V_{\max }\left(1-\left(\frac{\rho}{\rho_{\max }}\right)^{2}\right)
$$

dimana $\mathrm{V}_{\max }$ dan $\rho_{\max }$ secara berturut-turut merepresentasikan kecepatan dan kepadatan maksimum lalu lintas.

Lebih jauh lagi, substitusikan persamaan (2) dan (3) ke dalam persamaan (1), sehingga diperoleh persamaan diferensial hiperbolik orde satu yang menggambarkan model kepadatan lalu lintas, yaitu

$$
\frac{\partial \rho(x, t)}{\partial t}+\frac{\partial}{\partial x}\left(\rho V_{\max }\left(1-\frac{\rho^{2}}{\rho_{\max }^{2}}\right)\right)=0
$$

http://ejurnal.binawakya.or.id/index.php/MBI 


$$
x(t)-V_{\max }\left(1-\frac{3 \rho^{2}}{\rho_{\max }^{2}}\right) t=c, c \in R
$$

Asumsikan bahwa kepadatan lalu lintas pada saat awal pengamatan yaitu pada saat $\mathrm{t}=0$ adalah sebagai berikut:

$$
\rho(x, 0)=\rho_{0}(x)
$$

Dengan demikian, persamaan (4) dan (5) merupakan masalah nilai awal yang akan diselesaikan secara analitik dan numerik pada subbab berikutnya.

\section{Metode Karakteristik}

Masalah nilai awal yang diberikan oleh persamaan (4) dan (5) akan diselesaikan dengan metode karakteristik. Pertama-tama, tuliskan persamaan (1) ke dalam bentuk aturan rantai yaitu

$$
\frac{\partial \rho}{\partial t}+\frac{\partial q}{\partial \rho} \frac{\partial \rho}{\partial x}=0
$$

Sedangkan hubungan antara fluks, kepadatan, dan kecepatan lalu lintas dapat diperoleh melalui persamaan (2) dan (3) yaitu

$$
q(\rho)=\rho V_{\max }\left(1-\left(\frac{\rho}{\rho_{\max }}\right)^{2}\right)
$$

sehingga diperoleh

$$
\begin{aligned}
& \frac{\partial q}{\partial \rho}=\frac{\partial}{\partial \rho}\left(\rho V_{\max }\left(1-\left(\frac{\rho}{\rho_{\max }}\right)^{2}\right)\right) \\
& \frac{\partial q}{\partial \rho}=V_{\max }\left(1-\frac{3 \rho^{2}}{\rho_{\max }^{2}}\right)
\end{aligned}
$$

Berdasarkan persamaan (8), maka persamaan (6) dapat dituliskan sebagai berikut

$$
\frac{\partial \rho}{\partial t}+V_{\max }\left(1-\frac{3 \rho^{2}}{\rho_{\max }^{2}}\right) \frac{\partial \rho}{\partial x}=0
$$

Berdasarkan metode karakteristik (Khabir, 2010), maka dari persamaan (9) diperoleh

$$
\frac{\partial x}{\partial t}=V_{\max }\left(1-\frac{3 \rho^{2}}{\rho_{\max }^{2}}\right)
$$

sehingga persamaan garis karakteristiknya (Strauss, 2010) adalah
Solusi dari persamaan (9) sepanjang garis karakteristik (11) adalah

$$
\rho(x, t)=f\left(x(t)-V_{\max }\left(1-\frac{3 \rho^{2}}{\rho_{\max }^{2}}\right) t\right)
$$

untuk sebarang fungsi f.

Ingat bahwa kita memiliki syarat awal (5), sehingga dari persamaan (12) diperoleh

$$
\begin{aligned}
& \rho(x, 0)=f(x)=\rho_{0}(x) \\
& \rho(x, t)=\rho_{0}\left(x(t)-V_{\max }\left(1-\frac{3 \rho^{2}}{\rho_{\max }^{2}}\right) t\right)
\end{aligned}
$$

Persamaan (14) merupakan solusi analitik untuk masalah nilai awal (4) dan (5). Perhatikan bahwa solusi kepadatan lalulintas tersebut merupakan solusi implisit.

\section{Skema Beda Hingga}

Pada subbab ini, masalah nilai awal yang diberikan oleh persamaan (4) dan (5) akan disimulasikan secara numerik melalui metode beda hingga. Turunan pertama kepadatan lalu lintas terhadap waktu dan posisi dihampiri secara berturut-turut dengan skema beda maju dan beda mundur (Kiusalaas. J, 2010), yaitu:

$$
\begin{aligned}
\frac{\partial \rho(x, t)}{\partial t} \approx & \frac{\rho(x, t+\Delta t)-\rho(x, t)}{\Delta t} \\
& \frac{\partial \rho(x, t)}{\partial x} \approx \frac{\rho(x, t)-\rho(x-\Delta x, t)}{\Delta x}
\end{aligned}
$$

Sedangkan untuk fluks digunakan hampiran sebagai berikut

$$
\frac{\partial q(x, t)}{\partial x} \approx \frac{q(x, t)-q(x-\Delta x, t)}{\Delta x}
$$

sehingga skema beda hingga FTBS (Forward Time Backward Space) untuk persamaan diferensial parsial (1) adalah

$$
\rho_{j}^{i+1}=\rho_{j}^{i}-\frac{d t}{d x}\left(q_{j}^{i}-q_{j-1}^{i}\right)
$$

dan dari persamaan (7) dapat diperoleh 


$$
\begin{gathered}
q_{j}^{i}=\rho_{j}^{i} V_{\max }\left(1-\left(\frac{\rho_{j}^{i}}{\rho_{\max }}\right)^{2}\right) \\
q_{j-1}^{i}=\rho_{j-1}^{i} V_{\max }\left(1-\left(\frac{\rho_{j-1}^{i}}{\rho_{\max }}\right)^{2}\right)
\end{gathered}
$$

Perhatikan bahwa persamaan (18) adalah bentuk skema beda hingga yang masih mengaitkan antara fluks (q) dan kepadatan $(\rho)$. Oleh karena itu, substitusikan persamaan (19) dan (20) ke dalam persamaan (18) untuk memperoleh skema beda hingga yang hanya

bergantung pada kepadatan saja, sehingga diperoleh

$$
\begin{gathered}
\rho_{j}^{i+1}=\rho_{j}^{i}\left(1-\frac{d t}{d x} V_{\max }\right)+\frac{d t}{d x} \rho_{j-1}^{i} \cdot V_{\max }(1- \\
\left.\left(\frac{\rho_{j-1}^{i}}{\rho_{\max }}\right)^{2}\right)
\end{gathered}
$$

\section{HASIL DAN PEMBAHASAN Simulasi}

Pada bagian ini akan diberikan beberapa contoh kasus untuk disimulasikan. Simulasi ini dilakukan untuk mengetahui kecenderungan perubahan arus lalu lintas juka data diubah ubah.

Data simulasi yang digunakan pada subbab ini berasal dari data sekunder yang dilakukan oleh M.H. Khabir (2010).

Pada kasus yang pertama, akan diambil suatu nilai awal yang berupa fungsi yaitu

$$
\rho(x, 0)=f(x)=\rho_{0}(x)=x / 2
$$

Pemilihan nilai awal kepadatan yang berupa fungsi ini bertujuan agar kita bisa mendapatkan solusi analitik dari (14) secara eksplisit.

Pertama-tama, substitusikan persamaan (22) ke dalam (14) sehingga diperoleh

$$
\rho(x, t)=\frac{1}{2}\left(x-V_{\max }\left(1-\frac{3 \rho^{2}}{\rho_{\max }^{2}}\right) t\right)
$$

Melalui manipulasi aljabar maka diperoleh persamaan kuadrat dalam fungsi $\rho(x, t)$ yaitu

$$
3 V_{\max } t \rho^{2}-2 \rho_{\max } \rho+\left(x-V_{\max }\right) \rho^{2}{ }_{\max }=0
$$

sehingga solusi dari (23) adalah

$\rho(x, t)=\frac{\rho^{2} \max _{\max } \pm \sqrt{\rho_{\text {max }}^{4}-3 V_{\max } t\left(x-V_{\max } t\right) \rho^{2} \text { max }}}{3 V_{\max } t}$

Perhatikan

bahwa

nilai

$\rho_{\text {max }}^{2} \pm \sqrt{\rho^{4} \max -3 V_{\max } t\left(x-V_{\max } t\right) \rho^{2}{ }_{\text {max }}}$ akan

melebihi nilai $\rho_{\max }$ sehingga kita pilih bahwa solusi analitik dari persamaan (4) dengan kepadatan awal (22) adalah

$\rho(x, t)=\frac{\rho_{\text {max }}^{2}-\sqrt{\rho_{\text {max }}^{4}-3 V_{\text {max }} t\left(x-V_{\text {max }} t\right) \rho_{\text {max }}^{2}}}{3 V_{\text {max }} t}$

Misalkan kita mengamati suatu ruas jalan yang panjangnya $10 \mathrm{~km}$ selama 6 menit. Asumsikan kepadatan jalan (banyaknya kendaraan) pada jarak $0 \mathrm{~km}, \rho(0, \mathrm{t})$ adalah tetap yaitu sebesar $21 / \mathrm{km}$, kepadatan jalan maksimum pmax $=250 / \mathrm{km}$ dan kecepatan arus jalan maximum $V \max =60 \mathrm{~km} / \mathrm{jam}$.

Pada kasus kedua ini, kepadatan awal jalan $\rho(x, 0)$ tidak diberikan berupa fungsi seperti pada kasus 1. Kepadatan awal jalan diberikan dalam bentuk grafik yang ditunjukkan oleh Gambar 1 .

\section{Gambar 1. Kepadatan jalan awal, $\rho(x, 0)$}

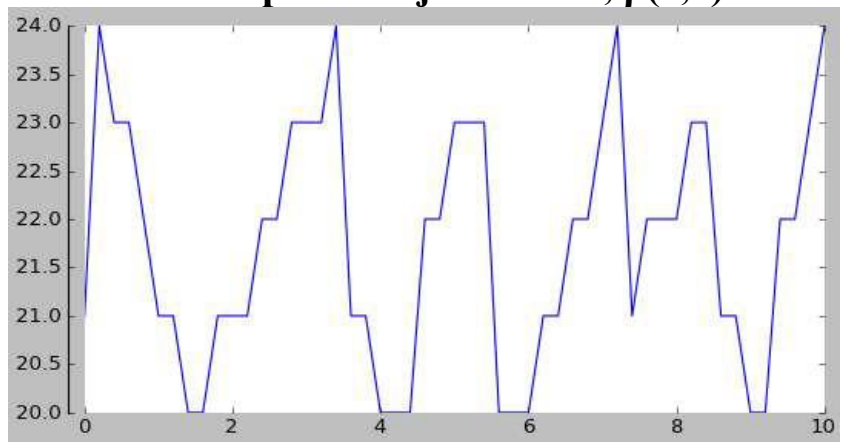

Perhatikan Gambar 1, gambar tersebut menunjukkan bahwa kepadatan awal tidak dapat http://ejurnal.binawakya.or.id/index.php/MBI 
dinyatakan ke dalam suatu fungsi yang sederhana. Dengan demikian, kita tidak dapat mencari solusi analitiknya secara eksplisit, sehingga pada kasus ini hanya akan dilihat solusi numeriknya saja.

Ingat bahwa hubungan antara kecepatan dan kepadatan arus lalu lintas yang kita miliki adalah non linear yang diberikan oleh persamaan berikut

$$
V(\rho)=V_{\max }\left(1-\left(\frac{\rho}{\rho_{\max }}\right)^{2}\right)
$$

Berdasarkan hubungan (27) tersebut, dapat kita lihat bahwa kecepatan lalu lintas akan nol ketika kepadatan lalu lintas sama dengan kepadatan maximum yang dapat dicapai oleh ruas jalan.

Lebih jauh lagi, perhatikan gambar 2 dan gambar 3. Nilai kecepatan lalu lintas tidak pernah mencapai nol, karena kepadatan lalu lintas tidak pernah mencapai nilai kepadatan maksimum yang dapat ditampung oleh jalan tersebut. Lebih rinci lagi, kepadatan terbesar yang dicapai adalah 24/km (yaitu saat $\mathrm{t}=0$ ), sedangkan kepadatan maksimum jalan adalah $\rho \max =250 / \mathrm{km}$, sehingga kecepatan lalu lintas tidak pernah nol.

Berdasarkan gambar 2 dan gambar 3 kita juga dapat melihat bahwa seiring dengan bertambahnya waktu dan jarak, maka nilai kepadatan dan kecepatan lalu lintas semakin tidak fluktuatif atau dengan kata lain semakin homogen. Hal ini jelas masuk akal, mengingat bahwa kepadatan lalu lintas bisaanya akan terurai dengan sendirinya walaupun dalam waktu yang sangat lama. Kepadatan awal juga memberikan pengaruh yang besar terhadap perubahan kepadatan dan kecepatan lalu lintas di setiap titik. Gambar 2 Profil Kepadatan lalu lintas, $\rho(x, t)$

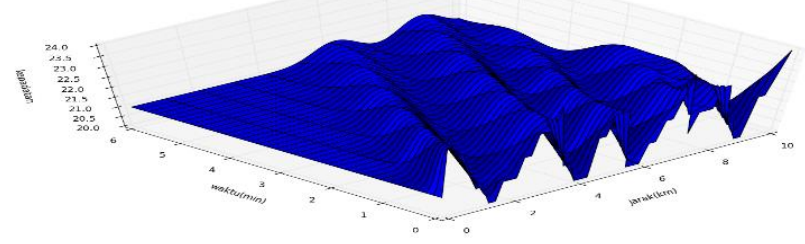

Gambar 3. Profil Kecepatan lalu lintas, v(x,t) http://ejurnal.binawakya.or.id/index.php/MBI Open Journal Systems

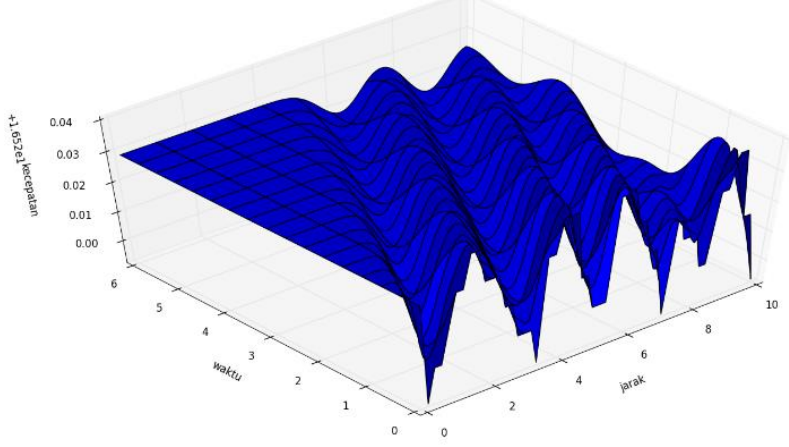

Selain itu, dari hubungan (27) juga diperoleh bahwa semakin besar nilai kepadatan lalu lintas $\rho$, maka kecepatan arus lalu lintas V semakin kecil. Hal ini terlihat juga pada gambar 2 dan gambar 3 Saat kepadatan lalu lintas $\rho$ konstan, maka kecepatan lalu lintas juga konstan. Keadaan ini sudah sesuai dengan grafik fundamental dari kepadatan lalu lintas yang diberikan pada gambar 1 .

Gambar 4. Profil Kepadatan lalu lintas pada beberapa waktu yang berbeda

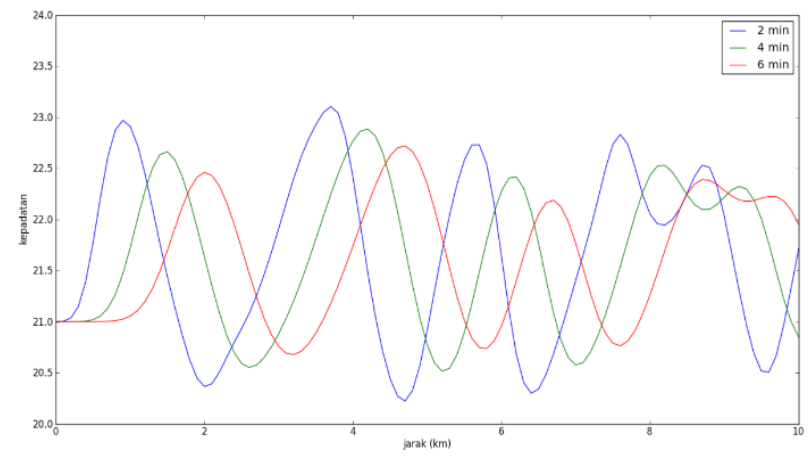

Gambar 5. Profil kecepatan lalu lintas pada beberapa waktu yang berbeda

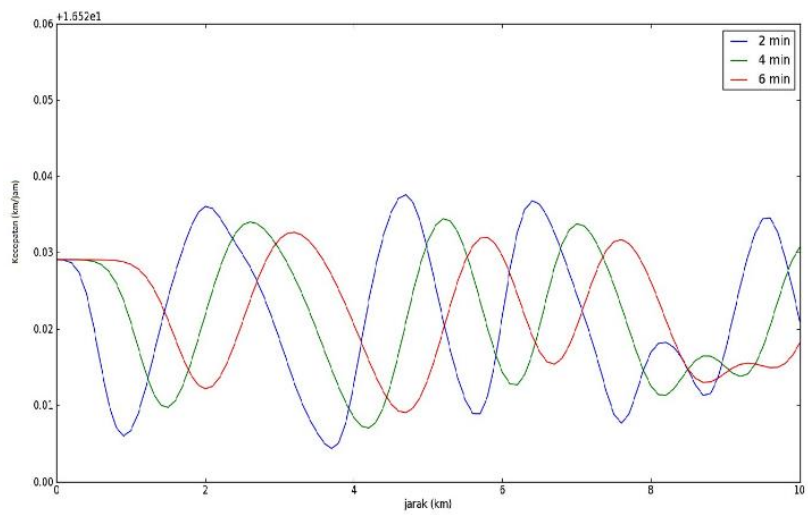

Lebih detail lagi, gambar 4 dan gambar 5 secara berturut-turut menggambarkan profil kepadatan dan kecepatan lalu lintas pada saat 2

Vol.14 No.4 Nopember 2019 
menit, 4 menit, dan 6 menit. Perhatikan bahwa pada saat $\mathrm{t}=2$ menit, kepadatan dan kecepatan arus lalu lintas mulai terlihat berbeda ketika $\mathrm{x}>$ $0.25 \mathrm{~km}$. Saat $\mathrm{t}=4$ menit, kepadatan dan kecepatan arus lalu lintas mulai terlihat berbeda ketika $\mathrm{x}>0.5 \mathrm{~km}$. Saat $\mathrm{t}=6$ menit, kepadatan dan kecepatan arus lalu lintas mulai terlihat berbeda ketika $x>1 \mathrm{~km}$. Dengan demikian, seiring dengan bertambahnya waktu, maka semakin jauh dari titik asal kita akan merasakan perubahan kepadatan dan kecepatan lalu lintas.

\section{Gambar 6. Profil fluks lalu lintas}

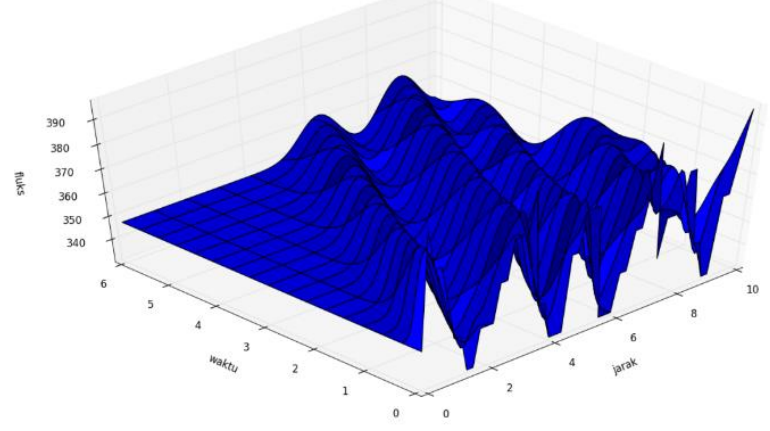

Gambar 7 Profil fluks lalu lintas pada beberapa waktu yang berbeda

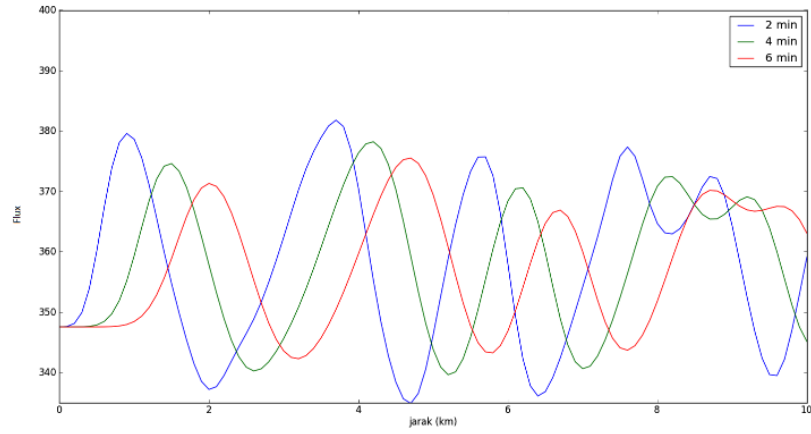

Sudut pandang yang berbeda (Fluks dan Kepadatan) menghasilkan permukaan yang berbeda pula. Hal ini disebabkan karena kepadatan melihat jumlah kendaraan yang ada pada suatu ruas jalan. Sedangkan fluks adalah banyaknya kendaraan yang lewat selama waktu tertentu.

\section{PENUTUP}

\section{Kesimpulan}

Dinamika fluida telah diterapkan untuk memodelkan arus lalu-lintas dengan menggunakan metode LWR. Metode LWR yang meninjau ruas jalan secara global dapat mengambil kesimpulan yang lebih obyektif dan merata pada setiap ruas jalan di waktu tertentu. Dengan mengubah kondisi awal sebuah ruas jalan dan jumlah kendaraan yang masuk pada titik awal, maka kepadatan pada ruas jalan tersebut juga mengalami perubahan.

Kepadatan lalu lintas dimodelkan oleh persamaan transport yang diberikan secara implicit, dengan syarat awal dan syarat batas diketahui. Solusi dari masalah nilai awal dan batas tersebut dapat memberikan gambaran mengenai kepadatan, kecepatan dan fluks pada sebuah ruas jalan dengan kondisi tertentu baik secara numerik maupun analitik. Solusi analitik dan numerik memberikan keseuaian baik secara kuantitatif maupun kualitatif.

Simulasi menunjukan bahwa semakin tinggi kepadatan lalu lintas, maka semakin kecil kecepatan arus lalu lintas. Solusi numerik juga menunjukan bahwa perhitungan bisa dilakukan jika dan hanya jika diskritisasi jarak jauh lebih besar dibanding diskritisasi waktu. Dengan kata lain, diskritisasi jarak dan waktu harus memenuhi syarat kestabilan. Hal tersebut bertujuan agar hasil yang diperoleh menjadi well posed, sedangkan jika diskritisasi waktu lebih besar atau sama dengan diskritisasi jarak, maka akan diperoleh hasil yang ill posed.

Bukan hanya kepadatan lalu lintas, model makroskopik yang diimplementasikan dalam suatu pemograman juga dapat digunakan untuk memprediksi kecepatan serta fluks lalu lintas pada titik dan waktu terntentu.

\section{DAFTAR PUSTAKA}

[1] Harahap, E., Suryadi, S., Darmawan, D., \& Ceha, R. (2017). Efektifitas Load Balancing Dalam Mengatasi Kemacetan Lalu Lintas. Jurnal Matematika Vol. 16 No. 2

[2] Kabir, M.H., Gani, M.O, (2010). Numerical Simulation Of A Mathematical Traffic Flow Model Based On A Nonlinear VelocityDensity Function. Journal of Bangladesh Academy of Sciences, Vol. 34, No. 1, 15-22.

[3] Kiusalaas, J.,( 2010). Numerical Methods In Engineering with Python. New York: Cambridge University Press

http://ejurnal.binawakya.or.id/index.php/MBI 
[4] Mardiati, Rina., Ismail, N., Faroqi, A., (2014). Review Of Microscopic Model For Traffic Flow. ARPN Journal of Engineering and Applied Sciences VOL. 9, NO. 10

[5] M. J. Lighthill and J. B. Whitham. (1955). On kinematic waves. $i$ : Flow movement in long rivers. ii: A theory of traffic flow on long crowded roads. Proc. Royal Soc. London Ser. A, (229):281-345

[6] Strauss, W.A., (2008). Partial Differential Equation An Introduction. USA:John Wiley \& Sons, Inc

[7] Tomara, S.A, Singhc, M., \& Sharmad, G., (2018). Traffic Management using Logistic Regression with Fuzzy Logic. Procedia Computer Science Volume 132, 2018, Pages $451-460$ 
HALAMAN INI SENGAJA DIKOSONGKAN 